\title{
Instructions to Contributors
}

\section{Editorial Policy}

The Journal of Global History seeks scholarly articles that explore global change. Conscious of past historiographical inequities, the journal particularly welcomes contributions from Asia, Africa and Latin America. The editors appreciate submissions from both senior figures in the field and younger scholars wishing to situate detailed research in a wider context. The journal also publishes survey articles, think-pieces and selected book reviews. The editorial philosophy is to encourage disciplined diversity, disciplined through rigorous peer-review, and diverse in points of view. Every yearly volume of the journal consists of three parts.

Reviews of books: The journal only publishes reviews that centrally address problems of global history. Publishers are invited to send to the Reviews Editor announcements of forthcoming or recently published books that they think would be of interest to global historians. They are asked not to send books for review unless specifically required to do so. Unrequested books will not be returned. Requested books should be sent to the LSE address indicated below.

\section{Reviews Editor}

\section{Dr Ronald C. Po}

Department of International History

London School of Economics and Political Science

Houghton Street

London WC2A 2AE, UK

E-mail: jgh.reviews@cambridge.org

\section{Submission}

If at all possible, articles submitted for consideration should be e-mailed, as Microsoft Word attachments (please do not use pdf files), to: jgh@cambridge.org

Length: Articles should be no longer than 12,500 words, including footnotes, unless authors obtain previous permission from the editors. The length of review articles and reviews will be set on a case by case basis by editors.

Language: All material should be written in English, and an English translation of all quotations in another language must be provided.

Conditions: Submission will be taken to imply that material is unpublished in an academic journal or book, and is not being considered for publication elsewhere, even in a language other than English. Exceptions may be made for articles published elsewhere in minority languages.

\section{Manuscript preparation}

Once an article has been accepted for publication in principle, authors should make any revisions requested by editors. The final version should be sent as an e-mail attachment in Microsoft Word, to the e-mail address given above. In cases of hard copy, two copies should be sent to the above address, double-spaced throughout, including notes.

An abstract: of 100-150 words should be provided. Bibliography: Do not include a consolidated list of references at the end of the article.

Footnotes: should be numbered consecutively throughout and appear at the foot of the page, or at the end of the article.

Tables: should be placed at the end of the article, and clear instructions should be provided for the typesetter as to where each one should be inserted in the text.

A descriptive heading and references to sources must accompany each table.
Illustrations: should if possible be digital, of high resolution (300 dpi), and transmitted electronically. In some cases, they may be sent on a computer disk (Macintosh or PC) to the above address. If photographs are sent by post, they should be black and white glossy prints. Maps sent by post must be submitted in camera-ready form. All illustrations should be clearly referenced in the text, and references to sources and descriptive headings must be attached.

A mailing address: should be supplied separately for the author(s).

\section{Text conventions}

Spelling: British with 'ize' preferred over 'ise'. Where foreign language words have achieved common currency, they should not be italicised and accents should be omitted - e.g. elite. Foreign words not assimilated into English (e.g. santri) should be italicised throughout, not just where they occur for the first time, and should have the necessary accents or diacritics. Capitals should be kept to a minimum, but should always be used where individual people or places are referred to specifically.

Numbers: up to 100 should normally be spelled in full. Days of the week and months of the year should appear in full, as should centuries, thus eighteenth century. In citations, the least number of figures should be used in connection with dates and pages - thus 241-5, except with the numbers 10-19 in each hundred, which should be cited as 112-13, not 112-3.

Abbreviations: should be followed by a full point; contractions should not. Full points should be omitted in initials which are read as words, as in USA, BBC, but retained for authors' initials, thus J. G. A. Pocock. Quotations: of more than 60 words should be separated out from the text and indented, without quotation marks. All citations in a language other than English should be translated into English, and should thus be kept short.

Footnotes: should be numbered in one sequence, identified by a superior number in the text, and appear at the foot of the page. They should not contain any substantive text, but should be used to indicate sources.

References should take the form of a full citation in the first instance, followed by short citations. Do not abbreviate journal titles. Ibid. should only be used to refer to the immediately preceding citation. Do not use op. cit. Please use the following conventions (note that these examples are in British English):

\section{Books first:}

Masykuri Abdillah, Responses of Indonesian Muslim intellectuals to the concept of democracy, 1966-1993, Hamburg: Abera, 1997, pp. 181-7.

Books subsequent:

Abdillah, Responses, pp. 190-1.

Articles first:

Sultana Afroz, 'From Moors to marronage: the Islamic heritage of the maroons of Jamaica', Journal of Muslim Minority Affairs, 19, 2, 1999 , pp. $114-15$.

Articles subsequent:

Afroz, 'From Moors to marronage', pp. 121-3.
Chapters in books first:

Yacine D. Addoun and Paul E. Lovejoy,

'Muhammad Kaba Saghanughu and the Muslim community of Jamaica,' in Paul E. Lovejoy, ed., Slavery on the frontiers of Islam, Princeton: Markus Wiener, 2004, pp. 199-202.

Chapters in books subsequent:

Yacine and Lovejoy, 'Muhammad Kaba Saghanughu', pp. 204-5.

Unpublished theses first:

Azyumardi Azra, 'The transmission of Islamic reformism to Indonesia: networks of Middle Eastern and Malay-Indonesian ulama in the seventeenth and eighteenth centuries,' $\mathrm{PhD}$ Thesis, University of Columbia, 1992, p. 123.

Unpublished theses subsequent:

Azra, 'The transmission', pp. 214-17.

Unpublished papers first:

Gulay Yarikkaya, 'Becoming a devsirme in the Ottoman empire,' unpublished paper for 'Children in Slavery' conference, Avignon, 19-21 May 2004 pp 1-4.

Unpublished papers subsequent:

Yarikkaya, 'Becoming a devsirme', p. 6.

Internet references first:

Hasan al-Banna, 'Peace in Islam', 1997, http:// www.youngmuslims.ca/online_library/books/ peace_in_islam/ (consulted 29 October 2004)

Internet references subsequent:

Banna, 'Peace in Islam'

Archives first:

Arsip Nasional Republik Indonesia, Jakarta, Residency Records (henceforth ANRI, RR) 29 , 580, Gouverneur van Amboina, 'Algemeen verslag', 29 December 1839.

Archives subsequent:

ANRI, RR, 30, 121, H. P. van Duyvenboden to H. van der Twist, Ternate, 18 August 1879.

\section{Copyright}

The author(s) will be asked to assign copyright (on certain conditions) to Cambridge University Press.

Contributors are responsible for obtaining permission to reproduce any material in which they do not hold copyright for world-wide publication in all forms and media, including electronic publication, and for ensuring that the appropriate acknowledgements are included in their text.

\section{Proofs}

Typographical or factual errors only may be changed a proof stage. The publisher reserves the right to charge authors for correction of non-typographical errors. Al amendments need to be agreed by the journal editors. Any corrections that contradict JGH house style will not be transferred. Authors are not shown second page proofs which are checked by journal.

The editors reserve the right to make final editorial decisions.

\section{Offprints}

Authors will receive a link to the PDF of their article after publication. Offprints may be purchased at proof stage. 


\section{Journal of Global History}

VOLUME 12 PART 3 - NOVEMBER 2017

\section{contents}

303 Circulation: reflections on circularity, entity, and liquidity in the language of global history Stefanie Gänger

319 When commerce, science, and leisure collaborated: the nineteenth-century global trade boom in natural history collections

Anne Coote, Alison Haynes, Jude Philp and Simon Ville

340 The category of 'family workers' in International Labour Organization statistics (1930s-1980s): a contribution to the study of globalized gendered boundaries between household and market Theresa Wobbe and Léa Renard

361 World health by place: the politics of international health system metrics, 1924-c. 2010 Martin Gorsky and Christopher Sirrs

386 Buying for Britain, China, or India? Patriotic trade, ethnicity, and market in the 1930s British empire/Commonwealth David Thackeray

410 Zones of reterritorialization: India's free trade zones in comparative perspective, 1947 to the $1980 \mathrm{~s}$ Megan Maruschke

433 REVIEWS 